\title{
KRITIK SEJARAH DALAM PENELITIAN HADIS
}

\author{
Taqna'in \\ Program Studi Ilmu Hadis \\ Universitas Islam Negeri Sunan Ampel Surabaya \\ taqnain@gmail.com
}

\begin{abstract}
Hadith has its own history which is incorporated in the history of Islamic development and even the history of world development. The flashback to the history of the hadith began when the Prophet Muhammad-may peace and blessings of Allah be upon him-was sent as a Prophet, the spread of the Prophet's hadith and the droves of the Companions studying Islam and the enthusiasm of next generation to relay the struggle. In selecting hadith, there are criteria that hadith scholars agreed in research by using several methods to determine the truth of leaning the news on the Prophet. Then came the researchers today who offer an alternative method of hadith research, namely the historical criticism method. The formulation of the problem in this research is about: (1) the meaning of historical criticism, (2) the comparison of historical criticism with hadith text and chain of narration criticism, (3) the relevance of the application of historical criticism to hadith research. The research method used is a qualitative method with a comparative descriptive approach. The result of this study indicates that: (1) Historical criticism is the process of collecting past data critically and systematically from related sources to be critically verified so that it can be interpreted objectively to produce accurate historical writing. (2) There are 4 forms of comparison between historical criticism and hadith text and chain of narration criticism (3) The historical criticism is not relevant to hadith research because there are things that are not accommodated in revealing the authenticity of a hadith, so that historical criticism cannot match the hadith text and chain of narration criticism.
\end{abstract}

Keywords: Historical Criticism, Hadith Research, Matan's Criticism, Sanad's Criticism.

\begin{abstract}
ABSTRAK
Hadis memiliki sejarahnya sendiri yang tergabung dalam sejarah perkembangan Islam bahkan sejarah perkembangan dunia.Kilas balik sejarah hadis bermula sejak diutusnya Nabi Muhammad shallahu'alaihi wasallam sebagai seorang Nabi, tersebarnya hadis Nabi dan berbondong-bondongnya para Sahabat mempelajari Islam dan semangatnya generasi penerus melanjutkan estafet perjuangan. Dalam menyeleksi hadis ada kriteria penelitiannya, dengan menggunakan beberapa metode untuk menentukan kebenaran penyandaran kabar kepada Nabi yang telah disepakati oleh para pakar hadis. Kemudian munculpara peneliti zaman sekarang yang menawarkan sebuah alternatif metode penelitian hadis dengan istilah kritik sejarah. Rumusan masalah dalam penelitian ini adalah tentang: (1) pengertian kritik sejarah, (2) perbandingan kritik sejarah dengan kritik sanad dan matan hadis, (3) relevansi penerapan kritik sejarah pada penelitian hadis. Metode penelitian yang dipakai adalah metode kualitatif dengan pendekatan deskriptif komparatif. Hasil dari penelitian ini menunjukkan bahwa: (1) Kritik sejarah adalah proses pengumpulan data masa lampau secara kritis dan sistematis terhadap sumber-sumber yang berkaitan untuk diverifikasi secara kritis sehingga dapat diinterpretasi
\end{abstract}


dengan objektif untuk menghasilkan penulisan sejarah yang akurat. (2) Ada 4 sisi perbandingan antara kritik sejarah dengan kritik sanad dan matan hadis. (3) Kritik sejarah tidak relevan pada penelitian hadis dikarenakan adanya hal-hal yang tidak terakomodir dalam mengungkap keotentikan sebuah hadis sehingga keberadaanya tidak bisa menandingi kritik sanad dan matan hadis.

Kata Kunci: Kritik Sejarah, Penelitian Hadis, Kritik Matan, Kritik Sanad.

\section{A. PENDAHULUAN}

Hadis memiliki sejarahnya sendiri yang tergabung dalam sejarah perkembangan Islam bahkan sejarah perkembangan dunia. Kilas balik sejarah hadis bermula sejak diutusnya Nabi Muhammad shallahu'alaihi wasallam sebagai seorang Nabi, tersebarnya hadis Nabi dan berbondong-bondongnya para Sahabat mempelajari Islam dan semangatnya generasi penerus baik dari kalangan tabiin, tabiut tabiin dan para ulama hadis setelah mereka, dalam rangka melanjutkan estafet perjuangan Nabi shallahu'alaihi wasallam menyebarkan Islam dan Sunnah demi terciptanya perdamaian dunia.

Dalam menyeleksi hadis,para ulama hadis telah membuat kriteria-kriteria penelitiannya dengan menggunakan beberapa metode untuk menentukan kebenaran penyandaran kabar kepada Nabi shallahu'alaihi wasallam yang telah disepakati oleh para pakar hadis. Sehingga atas berkat rahmat Allahsubhanahu wata'ala kemudian perjuangan mereka, umat Islam unggul dibanding umat lainnya dalam hal menjaga dan melesterikan sumber agamanya.

Bahkan kesaksian akan hal tersebut terlontar dari para ilmuwan dan cendekiawan di luar Islam, seperti Dr Asad Gabriel Rustum, seorang Ahli sejarah dan peradaban beragama Nasrani berkebangsaan Libia, berkata dalam bukunya Mușțalah al-Tarīkh:

Pencetus kritik riwayat sejarah dan yang pertama kali meletakkan pondasinya adalah para ulama agama Islam, karena mereka merasa perlu untuk menjaga perkatan Nabi dan perbuatannya, mereka mengatakan "Bukanlah ia (hadis) melainkan wahyu yang diwahyukan kepadanya", dan apa yang dibacakan olehnya adalah al-quran dan alsunnah. Sehingga mereka berusaha keras untuk mengumpulkan hadis-hadis, mempelajarinya dan menelitinya, hingga melahirkan ilmu hadis beserta kaidahkaidahnya yang hingga hari ini pondasi dan rangkaiannya masih dimuliakan dalam bidang ilmu pengetahuan" (Asad Rustum, 2017: 5-6).

Ia juga mengatakan setelah menyebutkan karangan ulama Islam dalam ilmu musthalah hadis seraya mengungkapkan kekagumannya: 
Suatu kenyataan, bahwa tidaklah mungkin para pakar sejarawan hari ini untuk menulis karangan yang lebih baik dari pada (apa yang telah dikarang oleh ulama Islam) meskipun hanya pada sebagian aspek pembahasannya, padahal hal tersebut sudah berlangsung selama tujuh abad lamanya. Sungguh apa yang terdapat dalam (karangan ulama Islam) berupa metodologi kejelian dan ketelitian pemikiran serta produk penelitian yang dihasilkan, mampu menandingi kajian setema (dalam sejarah) yang terdapat dalam buku-buku di negara Perancis, Eropa dan Amerika (Asad Rustum, 2017: 12).

Hadis Nabi shallahu'alaihi wasallam memang merupakan topik yang tidak pernah usang untuk dibahas. Segala aspek yang bisa dikaji akan dijadikan bahan pembahasan oleh seorang penulis. Terlebih lagi hadis merupakan salah satu sumber agama yang pokok selain alquran yang tidak selayaknya bagi seorang Muslim untuk mengingkari keotentikannya jika benar terbukti.

Namun para pembuat makar sepanjang sejarah tidak pernah tinggal diam, jika dahulu ada para penentang ajaran Nabi shallahu'alaihi wasallam, maka sampai hari inipun akan ada para penentang hadis Nabi shallahu'alaihi wasallam. Banyak cara yang dilakukan mereka untuk membuat makar dan propagandaterkait hadis. Dari mengkritik Sahih al-Bukhari yang merupakan kitab paling sahih setelah alquran, mendatangkan teori yang tidak pernah dipakai oleh para ulama hadis, sampai mempromosikan metode pemahaman hadis dengan sentuhan penafsiran bible?

Amat disayangkan banyak orang-orang yang mengaku cendekiawan dari kalangan intelektual kaum muslimin yang belajar dari mereka tanpa memiliki pondasi terhadap agamanya terlebih dahulu sehingga menelan mentah-mentah teori mereka. Meskipun kedatangan mereka membawa ghirah untuk membela agama ini dan memberikan bahan untuk menulis guna membantah mereka. Namun itu tidak sebanding dengan banyaknya generasi yang tercemari dengan noda-noda pemikiran nyeleneh mereka.

Salah satu cara mereka untuk menolak kehujjahan mayoritas hadis adalah mengenalkan metode kritik sejarah dalam penelitian hadis. Berlatar pemahaman mereka mengenai terlambatnya kodifikasi hadis yang berakibat terjadinya kesenjangan waktu antara peristiwa yang disampaikan dengan literatur hadis yang terkodifikasi. Hal ini menimbulkan keraguan akan keotentikan kitab-kitab hadis dalam merekonstruksi peristiwa-peristiwa yang terjadi pada masa lalu menurut mereka (Siregar, 2017: 50).

Padahal jika hadis dipelajari dari sumbernya, maka akan tampak bahwa hal itu tidak menimbulkan kesenjangan apapun. Karena metode ahli hadis itu lebih ketatdari pada metode 
ahli sejarah. Bahkan bisa dikatakan bahwa ilmu sejarah di dunia Islam lahir lebih muda dari pada ilmu hadis.

Oleh karena itu, makalah ini akan membahas mengenai hal tersebut dengan menitikberatkan pada maksud dari kritik sejarah dalam penelitian hadis dan mengkomparasikannya dengan metode kritik sanad dan matan hadis yang dilakukan ulama hadis.

\section{B.METODE PENELITIAN}

Penelitian ini termasuk penelitian pustaka dengan menggunakan metode kualitatif dan pendekatan deskritif komparatif. Sumber data dalam penelitian ini adalah buku-buku, desertasi, tesis, skripsi jurnal ilmiah yang bergubungan dengan tema penilitian. Data akan dikumpulkan dari sumbernya, kemudian dianalisis dan dijabarkan kemudian setelah itu dibandingkan antara satu dengan yang lainnya.

\section{HASIL DAN PEMBAHASAN}

\section{Penelitian Sejarah dan Kritik Sejarah menurut Ahli Sejarah}

Sejarah secara bahasa berasal dari bahasa Arab sajaratun yang berarti pohon, adapun sejarah dalam bahasa arab diartikan dengan tarikh (التاريخ) yang secara etimologi bermakna waktu (التوقيت) (al-Razi, 1420: 16). Definisi secara terminologi sejarah (التاريخ) terdapat banyak pendapat. Di antaranya Ibnu Khaldun berkata, "Deskripsi berita-berita tertentu berdasarkan masa atau generasi."(Ibnu Khaldun, 1984: 32). Sedangkan menurut Prof. DR. Kuntowijoyo sejarah adalah rekonstruksi masa lalu (Kuntowijoyo: 18).

Dalam penelitian suatu ilmu diperlukan metode, guna menjadikan penelitian tersebut terarah dan sesuai. Sehingga menjadikan penelitian itu bernilai objektif dan tidak subjektif. Kajian ilmu sejarah berupaya merekonstruksi masa lampau. Pekerjaan ini terbilang sulit meski terlihat gampang. Tidak jarang sejarawan sering mengalami kesulitan bahkan bisa dipastikan penyajian suatu kisah dari mereka pun tidaklah 100\% sesuai kejadian sesungguhnya (Mastaning, 2017: 28).

Oleh karena itu, peran metode penelitian sangat penting agar akurasi rekonstruksi bisa mendekati 100\% kejadian sesungguhnya. Adapun definisi metode penelitian sejarah menurut Mastaning adalah proses pengumpulan data masa lampau secara kritis dan sistematis terhadap 
sumber-sumber yang berkaitan untuk diverifikasi secara kritis sehingga dapat diinterpretasi dengan objektif untuk menghasilkan penulisan sejarah yang akurat.

Dari definisi di atas, ada lima tahap yang dilalui dalam penelitian sejarah, yaitu menentukan topik, mencari sumber, verifikasi (kritik sejarah, keaslian sumber), interpretasi: analisis dan sintesis, dan terakhir penulisan sejarahnya.

Kritik sejarah menjadi tahapan setelah kita menentukan topik dan menemukan sumber penelitian. Kritik sejarah atau verifikasi keabsahan sumber terdiri dari dua macam: kritik intern atau kebiasaan dipercayai (kredibilitas) dan kritik ekstern atau keaslian dari sumber (autentisitas).

Mastaning menyebutkan bahwa metode penelitian menurut Louis Gottchalk sebagai berikut:

a. Mengumpulkan objek yang berasal dari suatu zaman dan megumpulkan bahanbahan yang tertulis dan lisan yang relevan.

b. Menyingkirkan bahan-bahan (atau bagian-bagian daripadanya) yang tidak autentik.

c. Menyimpulkan kesaksian yang dapat dipercaya berdasarkan bahan-bahanyang autentik.

d. Menyimpulkan kesaksian yang dapat dipercaya itu menjadi suatu kisahatau penyajian yang berarti.

Sekilas dapat diambil benang merah antara pendapat Kuntowijoyo dan Louis Gottchalk mengenai langkah ataupun tahapan penelitian sejarah. Menurut hemat penulis, apa yang disebutkan Kuntowijoyo lebih simpel dan langsung terarah. Adapun yang disebutkan Louis Gottchalk merupakan penjelasan dari apa yang disebutkan oleh Kuntowijoyo.

\section{Hadis dan Penelitian Hadis}

Definisi Hadis menurut hadis menurut KBBI Daring secara etimologi berasal dari bahasa Arab (الحديث) yang berarti sabda, perbuatan, taqrir (ketetapan) Nabi Muhammad shallahu 'alaihi wasallam yang diriwayatkan atau diceritakan oleh sahabat untuk menjelaskan dan menetapkan hukum Islam. Definisi ini sejalan dengan definisi hadis dari sisi terminologis menurut ulama hadis (Ilyas, 2019: 3). 
Adapun penelitian hadis (kritik hadis) atau bahasa Arabnya naqd al-Hadiś memiliki definisi sebagaimana disebutkan oleh Muhammad Mustafa al-A'zhami: memilah hadis-hadis yang sahih dari yang lemah dan menilai kredibilitas rawi (al-A’ẓami, 1990: 5).

Senada dengan definisi di atas, (al-Jawabi, 1986: 94) Muhammad Ṭahir al-Jawabi menyebutkan bahwa ilmu kritik hadis adalah penilaian status cacat atau adil para periwayat hadis dengan menggunakan idiom khusus yang diketahui oleh para ahlinya, dan mencermati matan-matan hadis sepanjang telah dinyatakan sahih dari aspek sanad untuk tujuan mengakui validitas atau menilai lemah, dan upaya menyingkap kemusykilan pada matan hadis yang telah dinyatakan sahih, mengatasi gejala kontradiksi pemahaman hadis dengan mengaplikasikan kaidah-kaidah yang mendetail (Ilyas, 2019: 118).

Definisi di atas menggambarkan kepada kita bahwa penelitian hadis atau kritik hadis berfokus pada dua hal, sanad dan matan hadis. Pertama, kritik sanad hadis dengan meneliti kredibilitas seorang rawi apakah termasuk rawi terpecaya atau tidak, yang nantinya menghasilkan kesimpulan diterima atau tidaknya hadis atau kabar yang dia nukilkan.

Kedua, kritik matan hadis dengan menguji matan hadis tersebut dengan kaidah-kaidah yang digunakan untuk menimbang keaslian penyandarannya kepada Nabi ditinjau dari substansinya. Tahapan ini dilakukan secara hierarki, apabila tidak memenuhi standar kritik sanad maka tidak ada gunanya melanjutkan kritik matan (Ilyas, 2019: 119).

\section{Definisi Sejarah Menurut Ulama Hadis}

Definisi sejarah menurut Ulama Hadis adalah:

$$
\begin{aligned}
& \text { التعريف بالوقت الذي تضبط به الأحوال في المواليد والوفيات ويلتحق باه من الحوادث والوقائع } \\
& \text { التي ينشأ عنها معان حسنة من تعديل وتجريح ونحو ذلك }
\end{aligned}
$$

Mengetahui urutan waktu di mana kondisi ditentukan dengannya, pada hal-hal seperti kelahiran dan kematian, termasuk peristiwa dan insiden yang terjadi, yang mana hal ini menjadi sumber dari penilaian (terhadap rawi) secara ta'dII maupun tajīh ('Itr, 1981: 142).

Bisa dilihat bahwa sejarah menurut ulama hadis lebih spesifik ke biografi seorang rawi yang hal-hal yang mempengaruhi kredibilitasnya. Walau peristiwa yang dilalui si perawi terkadang juga direkam dalam kitab-kitab sejarah ulama hadis.

\section{Penelitian Hadis Menurut Ulama Hadis}


Hadis sebagai sumber pokok Islam setelah al-Qur'an terbagi dua menurut ulama usul fiqh: mutawatir dan ahad. Tidak seperti al-Qur'an yang keautentikannya disepakati. Namun para ulama hadis dalam meneliti hadis memiliki metode khas yang tidak terdapat pada ilmu mana pun, bahkan agama selain Islam pun tidak bisa menyamainya. Metode yang merupakan kekhususan umat Islam yaitu sanad. Dalam hal kritik matan pun, ulama hadis memiliki kaidahkaidah baku dalam memilah apakah matan hadis benar-benar ucapan Nabi atau kedustaan yang disematkan kepada beliau.

a. Kritik Sanad

Penelitian terhadap sanad (dirāsāt asānīd) merupakan penelitian terhadap status perowi hadis berdasarkan kredibilitasnya dalam menukil kabar. Ulama Hadis dikenal telah memulai kegiatan penelitian sanad sejak zaman sahabat (Ahmad Isnaeni: 2014).

Istilah yang dipakai oleh ulama hadis dalam hal ini adalah 'adālah (عدالة) kredibilitas. Ulama Ilmu Hadis mendefinisikan 'adālah dengan seorang muslim, baligh, berakal, terjaga dari perbuatan fasiq dan perkara yang bisa menjatuhkan kehormatannya (Al-Suyūți: 352).

A'zami mengomentari definisi di atas dengan berkata:

Bukanlah maksud (dari definisi itu) seseorang harus terbebas dari kesalahan dan dosa $100 \%$, karena hal tersebut hanyalah dimiliki orang yang maksum.Tapi maksudnya adalah seseorang itu berada di dalam keta'atan dalam mayoritas kehidupannya secara lahiriyahnya (Al-A'zami, 1990 :25).

Lebih luas lagi penelitian sanad berpusat pada syarat hadis sahih yang mana pengertian hadis sahih sebelum zaman Imam Syafi'i belum memiliki definisi yang disepakati (Al-Syayi, 2017: 5). Namun secara garis besar syarat hadis sahih kebanyakan terletak pada sanad hadis (Ilyas, $2019: 122$ ).

Penelitian sanad sebagai syarat hadis sahih meliputi:

1) 'Adālah dan Dobiț (al-Jarh wa al-Ta'dîl), penelitian berdasarkan keadilan periwayat dan segi hafalannya.

2) Ittișāl as-Sanad, penelitian ketersambungan sanad dari periwayatan satu ke lainnya.

3) As-Salāmah min asy-Syużuz wa al-'Illah, penelitian berdasarkan ada tidaknya cacat pada sanad dan matan hadisnya.

Ketiga atau bisa disebut kelima hal di atas menjadi kerangka acuan dalam penelitian sanad atau disebut juga naqd al-Khariji. 


\section{b. Kritik Matan}

Terdapat tuduhan tidak mendasar yang ditujukan kepada ulama hadis terkait kritik matan. Mereka menuduh bahwa ulama hadis hanya membatasi perhatian mereka pada mengetahui para periwayat hadis dan hal-ihwal sejarah mereka saja, tidak ada kewajiban lagi bagi mereka (untuk memeriksa) apakah hadis dari para periwayat itu sahih atau tidak, masuk akalatau tidak (Al-A’zami, 1990: 81).

Seakan mereka menuduh bahwa Sahabat dan Ulama Hadis lainnya tidak pernah menggunakan akal mereka untuk merenungkan apakah matan suatu hadis itu masuk di akal atau tidak? Muhammad Mustafa al-A'zami membantah hal tersebut. Ulama hadis lebih perhatian terhadap sanad dari pada matan itu benar. Tapi menuduh kalau mereka tidak menggunakan akal mereka untuk kritik matan itu salah besar.

Karena kritik itu pada dasarnya menggunakan akal, tapi ulama hadis tidak berpegang hanya pada akal semata dalam menghukumi matan hadis kecuali sangat jarang. Tidak mungkin juga menjadikan akal sebagai hakim di semua hadis.

Beliau menukil perkataan Imam Syafi'i, “Tidak dijadikan dalil atas benarnya hadis atau dustanya kecuali dengan kejujuran pemberi kabar atau kedustaanya, kecuali pada sebagian kecil dari hadis." Ulama hadis tidak hanya berhenti pada sanad hadis saja dalam memberikan hukum atas hadis tapi mereka selalu mencermati matan hadis sampai ada hadis yang dihukumi batil padahal sanadnya bersih dari cacat.

Ada semua kaidah umum di kalangan ulama hadis yang berbunyi

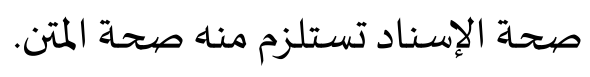

"Sahihnya suatu sanad melazimkan kesahihan matannya."

Kritik matan dilakukan setelah dinyatakan bahwa sanadnya sahih. Jika dinyatakan sanadnya lemah, kritik matan tidak perlu lagi karena sama dengan mengkritik sesuatu yang tidak jelas dari mana sumber beritanya. Dalam arti kata, setiap matan hadis mutlak memerlukan sanad (Ilyas, 2019: 124).

Dalam menghukumi keabsahan suatu matan hadis setelah diketahui kesahihan sanadnya. Al-Khatib al-Baghdadi menyebutkan indikator keabsahan suatu matan hadis apabila mengandung enam hal, yaitu:

1) Hadis itu tidak bertentangan dengan akal sehat.

2) Tidak bertentangan dengan hukum Al-Qur'an yang telah muhkam atau qath'i al-Dalalah. 
3) Tidak bertentangan dengan hadis mutawatir.

4) Tidak bertentangan dengan amalan yang telah menjadi konsensus ulama salaf.

5) Tidak bertentangan dengan dalil yang pasti.

6) Tidak bertentangan dengan hadis ahad lain yang kualitasnya lebih kuat.

Ibnu Qayyim ketika ditanya apakah mungkin mengetahui hadis palsu dengan dobit (standar tertentu) tanpa harus melihat (mencari) sanadnya? Lalu Beliau menyebutkan beberapa kaidah umum cara mengetahui hadis palsu (Al-A'zami, 1990: 88):

1) Kabarnya mengandung perkara-perkara besar yang tidak mungkin keluar dari seorang utusan Allah.

2) Kabarnya didustakan oleh panca indra.

3) Kabarnya mengandung kesombongan dan menjadi bahan olok-olokan.

4) Kabarnya bertolak belakang dengan as-Sunnah yang jelas.

5) Kabarnya yang berisi bahwa Nabi melakukan sesuatu yang nyata jelas dihadapan para sahabat dan mereka sepakat untuk menyembunyikan kabar ini.

6) Kabarnya terbukti batil dengan sendirinya.

7) Kabarnya tidak seperti perkataan para Nabi.

8) Kabarnya seperti resep obat.

9) Kabarnya menyelisihi al-Qur'an

10) Kabarnya berisi hadis yang lafaznya goyang.

Berbeda dengan M. Syuhudi Ismail, beliau mengemukakan bahwa langkah penelitian atau kritik matan ada tiga, yaitu: (1) meneliti matan dengan melihat kualitas sanad-nya; (2) meneliti berbagai lafal yang semakna; dan (3) meneliti kandungan matan (Ilyas, 2019 :124).

Kebanyakan buku dan artikel yang membahas kritik matan hadis, mereka selalu menyebutkan apa yang disebutkan Salah al-Din al-Adlabi mengenai pokok-pokok acuan dalam kritikmatan ada empat macam, yakni: (1) tidak bertentangan dengan petunjuk Al-Qur'an; (2) tidak bertentangan dengan hadis yang kualitasnya lebih kuat; (3) tidak bertentangan dengan akal sehat, indera dan sejarah; dan (4) susunan pernyataannya menunjukkan ciri-ciri sabda kenabian. Adapun sisanya merupakan pencabangan dari yang 4 ini.

\section{Perbandingan Metode Sejarah dan Metode Hadis dalam Penelitian Sumber Sejarah atau Hadis}


Muhammad Mustafa al-A'zami mencoba membandingkan antara metode sejarah dan metode ulama hadis dalam penelitian terhadap hadis. Berikut paparan singkat hasil perbandingannya (Al-A'zami, 1990: 96):

a. Langkah awal yaitu mengumpulkan sumber (informasi atau kitab bersejarah). Langkah ini menurut Muhammad Mustafa al-A'zami ada pada kedua jenis metode. Ulama hadis lebih unggul dalam hal mengumpulkan sumber dari pada sejarawan. Sejarawan hanya mendasarkan langkah awalnya pada sebuah asumsi atau 99\%nya hanya teori sejarah saja. Beda halnya dengan ulama hadis yang bisa mendapatkan satu naskah sejarah dari 40 atau 50 orang yang berbeda.

b. Langkah kedua yaitu verifikasi sumber. Sejarawan dalam melakukanverifikasi sumber melihat pada jenis tinta, jenis kertas dan tulisan yang digunakan pada sumber. Ulama hadis lebih unggul dalam melakukan verifikasi sumber. Mereka mensyaratkan adanya sanad yang tersambung dari sumber yang sampai kepada kita hingga penulis asalnya. Ditambah mereka mensyaratkan semua periwayat harus jujur dan kredibel. Ada pun cara yang dilakukan oleh sejarawan di atas, bukanlah sesuatu yang baru. Bahkan ulama hadis lebih dahulu mempraktikannya.

c. Langkah ketiga yaitu analisa sumber untuk memastikan makna dan kandungannya sesuai dengan keinginan penulisnya. Lagi-lagi ulama hadis unggul dalam hal ini. Ulama hadis di antara mereka ada yang menguasai kata-kata gharib dan ilmu bahasa, atau ahli dalam menukil sumber, atau ahli dalam mencari makna-makna kata. Terkadang keahlian ini terkumpul pada satu orang. Dalam kubu sejarawan belum ada yang seperti ini.

d. Langkah keempat yaitu kredibilitas kritik sanad untuk mengetahui kejujuran dari pembawa sumber atau bisa dikatan kejujuran dan 'adalah dari semua periwayat sumber. Tentu dalam hal ini ulama hadis unggul jauh, bagaimana tidak? Mereka mensyaratkan agar suatu kabar diterima jika periwayatnya adalah orang yang adil, terpercaya, berakal, baligh, bebas dari perbuatan fasiq dan hal-hal yang bisa merusak kehormatan. Terlebih jika periwayat pernah berbohong sekali saja, maka kabarnya akan tertolak walau pun sudah bertobat. Adapun sejarawan pertimbangan mereka hanya pada kejujuran pemilik sumber dan adilnya dalam menulis sumber. Mereka tidak peduli apakah dia nanti berbohong pada perkara lain atau tidak. Sedikit bahkan jarang dari mereka yang mengetahui biografi pemilik sumber dengan baik sebagaimana ulama 
hadis mengenal para periwayat hadis. Bahkan ulama hadis memiliki kitab khusus berisi sejarah mereka. Beda halnya dengan sejarawan yang tidak memiliki hal serupa.

Hasil dari perbandingan ini sudah sangat jelas sekali menggambarkan keunggulan metode ulama hadis.

\section{KESIMPULAN}

Kritik sejarah yang menjadi andalan sejarawan dalam upayanya mencari keautentikan sumber sejarah masih kalah jauh dengan metode ulama hadis dalam meneliti keautentikan riwayat hadis. Bisa dikatakan penerapan kritik sejarah dalam penelitian hadis tidaklah diperlukan. Bahkan sebaliknya metode ulama hadis seharusnya digunakan dalam ilmu sejarah.

Hasil dari penelitian ini menunjukkan bahwa:

1. Kritik sejarah adalah proses pengumpulan data masa lampau secara kritis dan sistematis terhadap sumber-sumber yang berkaitan untuk diverifikasi secara kritis sehingga dapat diinterpretasi dengan objektif untuk menghasilkan penulisan sejarah yang akurat.

2. Ada empat sisi perbandingan antara kritik sejarah dengan kritik sanad dan matan hadis.

3. Kritik sejarah tidak relevan pada penelitian hadis dikarenakan adanya hal-hal yang tidak terakomodir dalam mengungkap keotentikan sebuah hadis sehingga keberadaanya tidak bisa menandingi kritik sanad dan matan hadis.

\section{E. DAFTAR PUSTAKA}

'Itr, Nur ad-Dīn.Manhaj an-Naqd fi 'Ulūm al-Hadlís. Damaskus: Dar al-Fikr, 1981.

Afwadzy, Benny. "Kritik Hadis dalam Perspektif Sejarawan", Mutawatir: Jurnal Keilmuan Tafsir Hadis, Vol 7, No 1, 2017.

al-A'ẓami, Muhammad Musțafa.Manhaj an-Naqd 'inda al-Muhaddiśin Nasyatuhu wa Tān̄inhuhu. KSA: Maktabah al-Kauthar, 1990.

al-Jawabi, Muhammad Ṭahir.Juhūd al-Muhaddiśin fi Naqd Matn al-Hadiś an-Nabawi asySyarīf. Tunis: Muassasah 'Abd al-Karīm 'Abdullāh, 1986.

al-Razi, Muhammad Abu Bakr.Mukhtar ash-Shihah. Beirut: al-Maktabah al-`Asriyyah, 1420 $\mathrm{H}$. 
al-Syayi, ‘Abd al-‘Aziz.Dirāsāt al-Asānī̃d. Tunisia: Dar al-Mālikiyah, 2017.

as-Suyūți, 'Abd ar-Rahmān. Tadr̄̄o ar-Rā w⿳亠丷厂 Syarh Taqrīb an-Nawā wi. t.tp.: Dar Ṭabah, t.th.

Ilyas, Abustani dan La Ode Ismail Ahmad.Studi Hadis Ontologi, Epistemologi dan Oksiologi. Depok: Rajawali Pers, 2019.

Isnaeni, Ahmad,"Historitas Hadis Dalam Kacamata M. Mustafa Azami,"Journal Episteme, Vol.9 No. 2, 2014.

Khaldun, Ibnu.Muqaddimah,t.tp: Dar al-Qalam,1984.

Kuntowijoyo,Pengantar IImu Sejarah. Yogyakarta:Bentang,t.th.

Mastaning, Perbandingan Tingkat Validitas Metode Penelitian Sejarah dan Sanad Hadis (studi kasus Haji Wada') Tesis-UIN Alauddin. 2017.

Rustum, Asad. Mușțalah al-Tarīkh.Beirut: al-Maktabah al-‘Așriyyah, 2017.

Siregar, Ilham Ramadan, dkk."Kritik Sejarah Terhadap Hadis Menurut Ahmad Amin Analisis Terhadap Kitab Fajr al-Islām,” Jurnal at-Tahdis:Journal of Hadith Studies, Vol. 1, No. 1,2017 .

https://kbbi.kemdikbud.go.id/entri/hadis. Diakses pada 24 Oktober 2020. 